\title{
ロバスト視覚サーボシステムの $L_{2}$ ゲインによる制御性能解析
}

\author{
非会員 丸山章 ((侏)不二越, 北陸先端科学技術大学院大学) \\ 正員藤田政之（北陸先端科学技術大学院大学）
}

Stability and $L_{2}-$ Gain Performance Analysis for Robust Visual Servo System

Akira Maruyama, Non-member (NACHI-FUJIKOSHI, JAIST), Masayuki Fujita, Member (JAIST)

In this paper, we deal with disturbance attenuation property of a controller for the visual servo systems. First, based on Lyapunov stability theory, we propose an asymptotically stable controller without exogenous inputs, e.g. the joint torque disturbances and the motion of a target. Next we show that the proposed controller achieves disturbance attenuation in the $L_{2}$-gain sense, that is, the $L_{2}$-gain of the closed loop system from the exogenous inputs to the regulated outputs can be made sufficiency small with a suitable selection of the feedback gains. Finally, our experiments on an industrial manipulator are shown to evaluate the effectiveness of the proposed controller and $L_{2}$-gain performance analysis for the visual servo system.

キーワート : ロバスト視覚サーボ, 外乱減衰問題, $L_{2}$ ゲイン, リアプノフの定理

1.はじめに

マニピュレータの関節空間の制御において, マニピュレー タのもつ固有の性質を有效に利用し, リアプノフの方法に 基つく制御が注目を浴びている(1)(2).この方法はマニピュ レータのもつエネルギーの総和をリアプノフ関数として利 用して漸近安定性を保証する。そのため非線形性の豲密な 補償を必要としないなどの利点をもつことが知られている。 また有本 (2) は比例制御部に飽和を考慮した SP-D 制御則 を提案して，準自然ポテンシャル関数を利用してその有效 性を示している. その上, 安定性だけでなく制御性能の指標 として, 非線形 $H_{\infty}$ 最適化の観点からトルク外乱に関する ロバスト性が議論されてきている(2)(3).

また関節空間の情報だけでなく視覚センサの情報もリア ルタイムでフィードバックすることでマニピュレータを制 御する, 視覚サ一ボの研究が近年さかんに行われている(4). 視覚サ一ボの従来研究の多くは線形システムでそのモデル を与え, 極配置や LQ 法, $H_{\infty}$ 制御などにより，系の安定性 や制御性能についての考察を行なってきた(5) (7). しかしな がらマニピュレータダイナミクスは本来非線形システムで あるため,その動特性の補償を行なうことが重要となるが, ダイナミクスの影響は無視されていた.

橋本ら (8) はフィードバック線形化の手法に基づいてマニ ピュレータダイナミクスを補償して，観測対象の運動を適 応的に推定することで視覚サ一ボを達成している.しかし マニピュレータに対してトルク外乱が存在した場合の制御 性能は解析されていない，また推定則を構成するため制御
則の構造が非常に複雑になるという問題点がある、また筆 者ら (9)(10)や Kelly ら ${ }^{(11)(12)}$ は，関節空間の制御で注目を 浴びているリアプノフの方法に基つく制御則を与えた。し かし観測対象が運動しないという仮定のもとでの安定性の 解析のみであり，トルク外乱に対するロバスト性は考えら れていない。

そこで本稿では対象が運動する eye-in-hand 構造での平 面マニピュレータの視覚サーボシステムに対して, リアプ ノフの安定論に基づき漸近安定性を保証する非線形な制御 則をあたえる.その蹬，対象点の像の位置を利用したポテン シャル関数, 画像パラメータポテンシャルを用いる，それに より関節空間の制御において注目を浴びている SP-D 制御 則をあたえることが可能となった．また 2 次元回転群の性 質を利用してあたえることにより，提案する制御則は焦点 距離などパラメータを使用しないものとなっている.

そしてトルク外乱や対象の運動を外生信号としてとらえ， それに対するロバスト性を制御性能の指標としてあたえる ことを提案する，そのロバスト性をはかる指標として非線 形システムの $L_{2}$ ダインを用いる.とくに対象の運動を外 生信号ととらえて, そのロバスト性を考えることで, 推定則

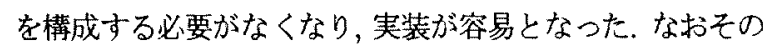
上, 実機による赛験を通じて提案する制御則の有効性を検 証する.

本稿の構成は以下のとおりである. まず第 2 節でマニピュ レータやカメラのモデリングを行ない, 視覚サーボの問題 設定を行なう. 第 3 節において外生信号が存在しない場合 に視敩サーボシステムを漸近安定にする制御則をあたえる。

電学論C, 118 巻 3 号, 平成 10 年 
その制御則は比例制御部に飽和関数を利用した非線形制御 則であり，安定性を解析するために画像パラメータポテン シャルを利用したリアプノフ関数を提案する.つぎに第 4 節では $L_{2}$ ゲインにより与えられた外乱減衰特性を達成す るための制御ゲインが満足しなくてはならない条件を尊出 する. $L_{2}$ ゲインの解析のための微分不等式の解として安定 性解析で提案したリアプノフ関数を利用した. 最後に実験 により提案した制御則の有効性を確認する.

以下で使用する記号の定義をおこなう。任意のベクトル $x \in \Re^{n}$ のニークリッドノルムを $\|x\|:=\sqrt{x^{T} x}$ と定義す る. 2 乗可積分関数空間を $L_{2}$ と表し, そのノルムをべクト ル值関数 $f(t) \in L_{2}$ に対して

$$
\|f(t)\|_{2}:=\sqrt{\int_{0}^{\infty}\|f(t)\|^{2} d t}
$$

と定義する.また有界なバクトル值関数全体の集合を $L_{\infty}$ とあらわす. 任意の $x=\left[x_{1} \ldots x_{n}\right]^{T} \in \Re^{n}$ に対して写像 $g(x):=\left[g_{1}(x) \ldots g_{m}(x)\right]^{T}$ が微分可能であるならば, $m \times n$ 次のヤコビアンはつぎのように定義できる.

$$
\frac{\partial g}{\partial x}:=\left[\begin{array}{ccc}
\frac{\partial g_{1}}{\partial x_{1}} & \cdots & \frac{\partial g_{1}}{\partial x_{n}} \\
\vdots & & \vdots \\
\frac{\partial g_{m}}{\partial x_{1}} & \cdots & \frac{\partial g_{m}}{\partial x_{n}}
\end{array}\right]
$$

\section{2. 視覚サーボシステムのモテリング}

本稿ではマニピュレータの手先に取り付けられたカメラ (eye-in-hand 構造) と観測対象点の相対位置を一定に保つ ように動かすことを制御目的とする. カメラモデルは標準 的な透視変換によりモデリングされるピンホールカメラと する. そして 2 次元回転群の性質を有効的に利用するため に, 指数行列を利用して定式化を行なう。ママニピュレータダ イナミクスは Euler-Lagrange 運動方程式で記述し, その 特徽を有効に利用した制御則を構成する.

〈2・1〉㭫標系の設定 本稿では 平面マニピュレータ を仮定し, 手先のカメラの運動と対象点の運動は平行な二 つの平面にそれぞれ拘束されているとする.つまり基淮座 標系 $\Sigma_{w}=\left\{\begin{array}{lll}X_{w} & Y_{w} & Z_{w}\end{array}\right\}$ に対してマニピュレータの動作 は座標系 $\Sigma_{w}$ の $X_{w}-Y_{w}$ 平面に拘束されている. マニピュ レータの手先のカメラの視線方向は $Z_{w}$ 軸と一致している と仮定する. またカメラには座標系 $\Sigma_{c}=\left\{X_{c} Y_{c} Z_{c}\right\}$ が 取り付けられており，これをカメラ座標系とよぶ. 画像面上 において座標系 $\Sigma_{i}=\left\{X_{i} Y_{i}\right\}$ を以下の条件を満足するよ うに定義する。

（1）画像面と光軸の交点が原点となる.

(2) 軸 $X_{i}$ と $Y_{i}$ が $X_{c}$ と $Y_{c}$ にそれぞれ平行になる.

そして $X_{c}-Y_{c}$ 平面と $X_{i}-Y_{i}$ 平面の間の距離, つまり焦点 距離は $l>0$ とする. 以上の座標系を図 1 に示す.

以上のように平面マニピュレータに構造を限定すること で, マニピュレータダイナミクスを含めた非線形システム
の安定性解析および制御性能解析が可能となる. また焦点 距離 $l$ や $Z_{w}$ 方向のカメラと対象との距離を決定をする必 要のない制御則を構成できることが示される.

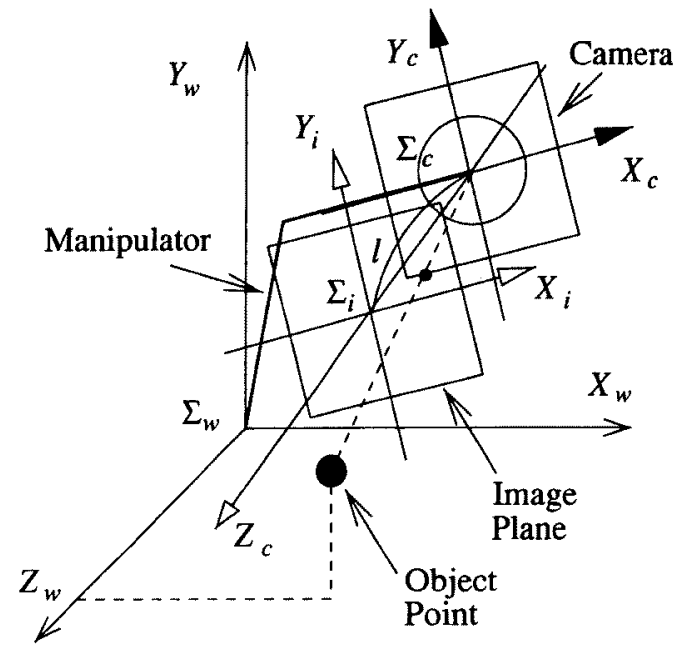

図 1 視覚サーボシステム

Fig. 1. Visual servo system

〈2・2〉 カメラモデル 対象点 $P$ の位置を座標系 $\Sigma_{w}$ において $\left[\begin{array}{lll}x_{p} & y_{p} & z_{p}\end{array}\right]^{T}$ であたえる. また対象点 $P$ の画像面 $\Sigma_{i}$ における位置は $f=\left[\begin{array}{ll}x_{i} & y_{i}\end{array}\right]^{T}$ であたえられるものとす る. 対象点 $P$ は $X_{w}-Y_{w}$ 平面上のみを運動すること,つま り $\dot{z}_{p}=0$ を仮定する. また $z_{p}>l$ とする.

カメラモデルとして理想的なピンホールカメラを考えて, 図 1のモデルに基づいて透視変換を利用することで以下の 関係式がえられる(9)(10).

$$
f\left(p, c, \theta_{c}\right)=\frac{s l}{d} e^{-\hat{\theta}_{c}}(p-c)
$$

ここで $s>0$ は画像面の計算機処理により生じるスケーリ ングファクタ $(\mathrm{pixel} / \mathrm{m}), d=z_{p}>0$ は奥行きの距離をあら わす定数とする. ベクトル $p \in \Re^{2}$ は $p:=\left[x_{p} y_{p}\right]^{T}, c \in \Re^{2}$ はカメラの $X_{w}-Y_{w}$ 平面上の位置をあらわし, $\theta_{\mathrm{c}} \in \Re$ はカ メラの $Z_{w}$ 軸回りの回転をしめす. また行列 $\hat{a}$ は任意のス カラ值 $a \in \Re$ に対して定義されるつぎの交代行列とする.

$$
\hat{a}:=\left[\begin{array}{cc}
0 & -a \\
a & 0
\end{array}\right]
$$

式(1)の両辺を微分することで,

$$
\dot{f}=\frac{s l}{d} e^{-\hat{\theta}_{c}} \dot{p}-\frac{s l}{d} e^{-\hat{\theta}_{c}} \dot{c}-\hat{\dot{\theta}}_{c} f
$$

がえられる．ここで $\dot{p}$ は対象の運動の速度信号であり, 未 知な量とする.

〔注意 1〕従来の視覚サーボの研究の多くは画像ヤコビア ン $\frac{\partial f}{\partial q}$ を直接計算して制御則を導出していた．本稿では 
式(1)のように指数関数による観点変換の表現を利用す

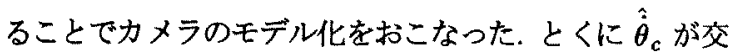
代行列である性質を安定性や制御性能解析で利用するこ とで,カメラパラメータの正確な同定の必要がない制御 則の提案と外生信号に対するロバスト性を考えることが 可能となった.

〈2・3〉 マニピュレータキネマティクス＼cjkstart本稿では eyein-hand 構造を仮定しているので, カメラの位置 $c$ と姿勢 $\theta_{c}$ はそれぞれマニピュレータの関節角度 $q \in \Re^{n}$ の関数と なる.ここでマニピュレータの関節速度 $\dot{q}$ とマニピュレー 夕の手先に取り付けられたカメラの速度の関係をもとめる ために, $c$ と $\theta_{c}$ の時間微分を計算すると，

$$
\begin{aligned}
\dot{c} & =J_{c}(q) \dot{q} \\
\dot{\theta}_{c} & =J_{\theta_{c}}(q) \dot{q}
\end{aligned}
$$

をえる.ここで $J_{c}(q)$ は $2 \times n$ 行列, $J_{\theta_{c}}(q)$ は $1 \times n$ べク トルであり，一般にマニピュレータヤコビアンとよばれる。

式(3)を式(2)に代入すると，最終的にカメラモデルとし て次式をえる。

$$
\dot{f}=\frac{s l}{d} e^{-\hat{\theta}_{c}} \dot{p}-\frac{s l}{d} e^{-\hat{\theta}_{c}} J_{c} \dot{q}-\hat{\dot{\theta}}_{c} f
$$

〈2・4〉マニピュレータダイナミクス＼cjkstart本節では平面 マニピュレータのダイナミクスのモデルとその性質を示寸 よく知られているようにマニピュレータダイナミクスは，

$$
\tau=M(q) \ddot{q}+C(q, \dot{q}) \dot{q}+g(q)+\omega
$$

で与えられる. ただし， $\tau \in \Re^{n}$ は入力トルクベタトル， $M(q)$ は $n \times n$ のマニピニレータ慣性行列, $C(q, \dot{q}) \dot{q}$ は $n$ 次のコリオリ・遠心トルクベクトル, $g(q)$ は $n$ 次の重カト ルクベクトルである. また $\omega \in \Re^{n}$ は摩摖力やモデル化誤 差などから生じるトルク外乱ベクトルとする．

マニピェレータダイナミクス $(6) を$ Euler-Lagrange シス テムとしてみなした場合，つぎの重要な性質が成立する(1)(2).

[性質 1] 慣性行列 $M(q)$ はすべての $q$ に対して対称加 正定な行列である.

〔性䝷 2] 行列 $\dot{M}(q)-2 C(q, \dot{q})$ はすべての $q$ と $\dot{q}$ K対 して交代行列となる. つまり任意のべクトル $x \in \Re^{n}$ に対 して $x^{T}(\dot{M}(q)-2 C(q, \dot{q})) x=0$ を満足する.

〈2.5〉問題設定本稿ではマニピュレータの制御目的 としてつぎの二つを考える.

(1) 対象との $X_{w}-Y_{w}$ 平面における相対位置 $p-c(q)$ を堿少させる.すなわち対象の画像面上の点像位置 $f$ を 0へ近づける.

（2）マニピュレータの各関節に過大な速度を発生させ ない.つまり, $\dot{q}$ を減少させる.

この制御目的を達成するためにまずトルク外乱や対象の運 動が存在しない場合に, $\dot{q} \rightarrow 0$ と $f \rightarrow 0$ を達成する制御
則を 3 節で提案する. 第 4 節ではトルク外乱や対象の運動 の外生信号に対するロバスト性を評価基淮にして, 制御則 のゲインを調整する方法をあたえる。

\section{3. リアプノフ法に基づく安定性解析}

本節ではトルク外乱や対象の運動が存在しない場合に，マ ニピュレータダイナミクスを利用した非線形制御則を示し その籁近安定性を証明する。

〈3.1〉 制御則の提案 本稿では視覚サーボ制御則とし て、つぎの非線形制御則を用いる.

$$
\tau=-k_{1} \xi+k_{2} \eta+\alpha(M(q) \dot{\eta}+C(q, \dot{q}) \eta)+g(q)(7)
$$

ここで $k_{1}, k_{2}, \alpha$ はそれぞれ正の数, ベクトル $\eta, \xi$ は

$$
\begin{aligned}
& \eta:=J_{c}^{T}(q) e^{\hat{\theta}_{c}} \varphi(f) \\
& \xi:=\dot{q}-\alpha \eta
\end{aligned}
$$

で定義される. また $\varphi: \Re^{2} \rightarrow \Re^{2}$ は飽和をあらわす関数 であり，任意の正の数 $\lambda \in \Re$ を用いて定義される.

$$
\varphi(f):=\frac{f}{1+\lambda\|f\|}
$$

飽和関数 $\varphi(f)$ はつぎの性質があることはあきらかである

〔性質 3〕 $\varphi(0)=0$ であり, $x \neq 0$ ならば $\varphi(x) \neq 0$.

制御則 (7)はつぎのような特徴がある.

・カメラパラメータ，つまり焦点距離 $l$ や奥行き $d$, ス ケーリングファクタ $s$ を利用しないので, カメラパラ メータの正確なキャリブレーションを必要としない．

・従来の視賞サーボ制御則の多くは、、ニピュレータヤ コビアンの逆行列の演算を必要としており，制御則の 演算時間がかかる問題があった (4). 制御則 (7) ではマ ニピュレータヤコビアン $J_{c}$ の逆行列の計算が必要でな い.よって計算時間が短縮され，実装が容易となる。

・補助変数 $\eta$ で利用した関数 $\varphi$ はあきらかに，

$$
\|\varphi(f)\|<\lim _{\|f\| \rightarrow \infty} \frac{\|f\|}{1+\lambda\|f\|}=\frac{1}{\lambda}
$$

である.つまりノルムが $\frac{1}{\lambda} に$ 漸近する飽和関数であり， 入により調整が可能である.これにより\|f\|が大きく なった場合に過大なトルク入力の発生をおさえること ができるなどの利点をもつ。

・ $\alpha$ を 0 に漸近させると制御則 (7) は従来のリアプノフ

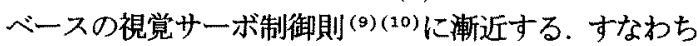
従来からの制御則の拉張したものである.

マニピュレータモデル (6),カメラモデル (5) および制御 則 (7)からなる閉ループ系は,

$$
\begin{aligned}
& M(q) \dot{\xi}+C(q, \dot{q}) \xi+k_{1} \xi-k_{2} \eta+\omega=0 \\
& \dot{f}=\frac{s l}{d} e^{-\hat{\theta}_{c}} \dot{p}-\frac{s l}{d} e^{-\hat{\theta}_{c}} J_{c} \dot{q}-\hat{\dot{\theta}}_{c} f \ldots \ldots .
\end{aligned}
$$

である.ここで外生信号を $r:=\left[\omega^{T} \dot{p}^{T}\right]^{T}$ と定義しておく 
〈3・2〉視覚サーボシステムの安定性解析 提案した制 御則 (7) の濑近安定性を示すために次の仮定をおく.

【仮定 1]マニピュレータの関節の動作範井を $Q \subset \Re^{n}$ と する. $q \in Q$ である任意の姿勢に対してマニピュレータ ヤコビアン $J_{c}$ は行フルランクである.

マニピュレータヤコビアンのランクがおちる場合は特異姿 勢である. 寸なわちマニピュレータの各関節が非常に大き な速度を発生する可能性がある，そこでマニピュレータの 構造的問題で制御目的が達成できないことを回避するため に仮定 1をおく，仮定 1によりつぎの補題が成立する.

〔補題 1】 $\left[\dot{q}^{T} f^{T}\right]^{T}=0$ と $\left[\xi^{T} \eta^{T}\right]^{T}=0$ は等洒である.

証明 付録参照

ここで外生信号 $r=0$ の場合, 閉ループ系 (9) が $\left[\begin{array}{ll}\xi^{T} & \eta^{T}\end{array}\right]^{T}=0$ において漸近安定となる条件をもとめる ためにつぎのようなリアプノフ関数の候補を考える。

$$
V=\frac{1}{2} \xi^{T} M \xi+\frac{k_{2} d}{s l} U(f)
$$

ここで $U(x)$ は $C^{2}$ 級の関数であり，任意の大きさの心゙ク トル $x$ に対してつぎのように与えられる.

$$
U(x)=\frac{1}{\lambda}\left(\|x\|-\frac{1}{\lambda} \log (1+\lambda\|x\|)\right)
$$

$\lambda$ は䳌和関数 $\varphi(f)$ に用いられていたものと同じである.こ のポテンシャル関数 $U(x)$ は以下のような性質をもつ.

〔性質 4〕任意のベクトル $x$ に対して $U(x) \geq 0$ である. とくに $x \neq 0$ では $U(x)>0$ である.

〔性質 5] ポテンシャル関数 $U(x)$ の $x$ に関する偏微分は,

$$
\frac{\partial^{T} U}{\partial x}=\varphi(x)
$$

となる.

証明 付録参照.

〔注意 2〕 正定関数 $V$ の第 1 項目は補助変数 $\xi に よ る$ 運 動エネルギーをあらわしている.また第 2 項目は画像面 上の特徵量 (ここでは対象点の像) の疑似ポテンシャル関 数で, 本稿では画像パラメータポテンシャルとよぶ.

画像パラメータポテンシャルを利用した関数 $(10)$ を用い て，閉ループ系 (9) の濑近安定性に関する結果をつぎのよ うにえることができる。

〔定理 1〕外生信号 $r$ が恒等的に 0 とする. ゲイン $k_{1}, k_{2}$

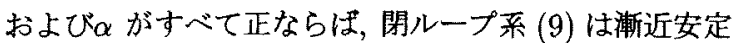
な平衡点 $\left[\xi^{T} \eta^{T}\right]^{T}=0$ をもつ.

証明 まず関数 $V$ の正定性は性質 1 と 4 および $k_{2}>0$ よ りあきらかであり，V=0 となるときは $\left[\xi^{T} \eta^{T}\right]^{T}=0$ の
場合のみである.つぎに関数 $V$ を $r=0$ とおいた場合の 閉ループ系 (9) の解軌道に沿って時間微分を行なうと

$$
\begin{aligned}
\dot{V}= & -\xi^{T} C(q, \dot{q}) \xi-k_{1}\|\xi\|^{2}+k_{2} \xi^{T} \eta+\frac{1}{2} \xi^{T} \dot{M}(q) \xi \\
& -k_{2} \dot{q}^{T} J_{c}^{T} e^{\hat{\theta}_{c}} \varphi(f)+\frac{k_{2} d}{s l(1+\lambda\|f\|)} f^{T} \hat{\dot{\theta}}_{\mathfrak{c}} f \\
& +\left[-\xi^{T} k_{2} \varphi^{T}(f) e^{-\hat{\theta}_{c}}\right] r \\
= & -\frac{1}{2} \xi^{T}(\dot{M}(q)-2 C(q, \dot{q})) \xi \\
& +\frac{k_{2} d}{s l(1+\lambda\|f\|)} f^{T} \hat{\dot{\theta}}_{c} f-k_{1}\|\xi\|^{2}-k_{2} \alpha\|\eta\|^{2} \\
& +\left[-\xi^{T} k_{2} \varphi^{T}(f) e^{-\hat{\theta}_{c}}\right] \ldots \ldots \ldots \ldots(13)
\end{aligned}
$$

となる. 性質 $2 お よ ひ ゙ \hat{\dot{\theta}} か ゙$ 交代行列であることより，

$$
\begin{aligned}
& \xi^{T}(\dot{M}(q)-2 C(q, \dot{q})) \xi=0 \\
& f^{T} \hat{\hat{\theta}}_{c} f=0
\end{aligned}
$$

である.よって

$$
\begin{aligned}
\dot{V}=-k_{1}\|\xi\|^{2}- & k_{2} \alpha\|\eta\|^{2} \\
& +\left[-\xi^{T} k_{2} \varphi^{T}(f) e^{-\hat{\theta}_{c}}\right] r
\end{aligned}
$$

となる. $r=0$ と各制御ダインが $k_{1}>0, k_{2}>0$, $\alpha>0$ より, $\dot{V}$ は負定関数であり, $\dot{V}=0$ が成立する のは $\left[\xi^{T} \eta^{T}\right]^{T}=0$ のときのみである. よってリアプノフ の直接法より (1), 平衡点 $\left[\xi^{T} \eta^{T}\right]^{T}=0$ は漸近安定性であ る.

定理 1より $t \rightarrow \infty$ で $\left[\xi^{T} \eta^{T}\right]^{T} \rightarrow 0$ が達成できることを 示した. よって補題 1 より $\left[\dot{q}^{T} f^{T}\right]^{T} \rightarrow 0$ が達成できる. しかし外生信号が存在する場合, $\dot{V}$ の負定性が成立しなく なるのは式 (14) よりあきらかである。 そこで次節では $L_{2}$ ゲインを用いた制御性能解析を行ない, 外生信号のロバス ト性を考察する。

\section{4. 視覚サーボシステムの制御性能解析}

〈4・1〉 消散性を利用した制御性能評価基準本節では まずはじめに, 外生信号のロバスト性の指標として $L_{2}$ ゲ インを用いるために非線形システムの消散性を用いてつぎ の問題を設定する。

問題 閉ループ系 (9)の被制御量として,

$$
z:=\left[\begin{array}{c}
\varepsilon_{1} \dot{q} \\
\varepsilon_{2} \varphi(f)
\end{array}\right]
$$

を考える. ここで $\varepsilon_{1}>0$ と $\varepsilon_{2}>0$ はそれぞれ重 みをあらわすスカラ值とする. 閉ループ系 $(9)$ が $w:=$

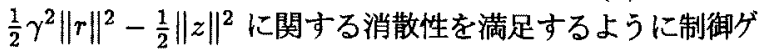
イン $k_{1}, k_{2}$ および $\alpha$ の条件を導出せよ.

ここで消散性の定義は以下のとおりである(13). 
〔定柾 1】状態空間表現されたつぎのような非線形システ ムを考える。

$$
\begin{aligned}
\dot{x} & =f(x, u) \\
z & =h(x, u)
\end{aligned}
$$

ここで $x \in \Re^{n}$ は状態ベクトル $u \in \Re^{m}$ は入力, $z \in \Re^{p}$ は出力ベクトルとする. また関数 $w(u, y) \in \Re$ を定義す る.この非線形システムが $w$ に関して消散性をもつと は,つぎの微分不等式の解 $S$ が存在することである 。

$$
\begin{aligned}
& S(x)>0, \quad x \neq 0 \\
& S(0)=0 \\
& \frac{\partial S}{\partial x} \dot{x} \leq \frac{1}{2} \gamma^{2}\|u\|-\frac{1}{2}\|z\|
\end{aligned}
$$

ここで $\frac{\partial S}{\partial x} \dot{\boldsymbol{x}}$ は $S$ のシステム (16) の解軌道に沿った時 間微分である。

〔注意 3〕 $\varepsilon_{1}, \varepsilon_{2}$ および $\gamma$ は視賞サーボの制御性能を决定 するパラメータである.とくに $\varepsilon_{1}$ と䄈は2.5 節で述心゙ た制御目的 (1) と (2) の間のトレードオフを調整するパ ラメータとなっている.

本稿では外生信号に対してつぎのような仮定をおく.

〔仮定 2〕 対象の速度信号 $\dot{p}$ およびトルク外乱 $d$ はそれ それ $L_{2} \cap L_{\infty}$ に属する.

この仮定のもとでは視覚サ一文問題の $w$ に対する消散性と 閉ループシステム $(9)$ における外生信号 $r$ から被制御量 $z$ への $L_{2}$ グインを $\gamma$ 以下にすることは等価になる(13).

外生信号から被制御量への $L_{2}$ ダインを $\gamma$ 以下にすること は外乱隇衰特性とよはれれ，外生信号に対するロバスト性を 示すのに重要かつ奏用的な指標となっている(2)(3). そこで 本稿では $L_{2}$ グインを $\gamma$ 以下にすることと等価な消散性を利 用して, 閉ループ系 (9) の制御性能を解析する。

〈4・2〉視党サーボシステムの制御性能の達成条件 マ ニピュレータの関節空間における制御で $L_{2}$ グインによる 外乱除去問題を取り报った徙来研究(3)で，安定性の解析 に利用したリアプノフ関数を微分不等式 (17) の解として取 り扱っている，そこで本稿では，視覚サーボ制御則 (7)の 安定解析に利用した画像パラメータポテンシャル関数に基 つくリアプノフ関数 $V$ を微分不等式 (17) の解ととらえて, 解析を行ない，つぎの結果をえた.

(定理 2) $k_{2}>0$ とする.つぎの対称行列

$$
R=\left[\begin{array}{ll}
R_{11} & R_{12} \\
R_{12}^{T} & R_{22}
\end{array}\right]
$$

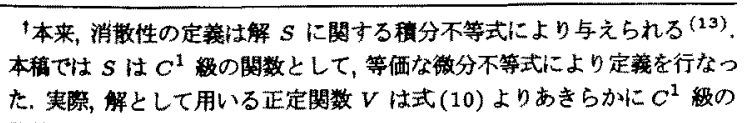
た、实際, 解と

電学䜽C，118巻 3 号, 平成 10 年

$$
\begin{aligned}
R_{11}= & \left(k_{1}-\frac{1}{2 \gamma^{2}}-\frac{\varepsilon_{1}^{2}}{2}\right) I \\
R_{22}= & \left(\alpha k_{2}-\frac{\alpha^{2} \varepsilon_{1}^{2}}{2}\right) e^{-\hat{\theta}_{c}} J_{c} J_{c}^{T} e^{\hat{\theta}_{c}} \\
& -\left(\frac{k_{2}^{2}}{2 \gamma^{2}}+\frac{\varepsilon_{2}^{2}}{2}\right) I \\
R_{12}= & \frac{1}{2} \alpha \varepsilon_{1}^{2} J_{c}^{T} e^{\hat{\theta}_{c}}
\end{aligned}
$$

が正定行列となるようにゲイン $k_{1}, k_{2}, \alpha$ を決定するな らは，閉ループシステム (9) は $w=\frac{1}{2} \gamma^{2}\|r\|^{2}-\frac{1}{2}\|z\|^{2} に$ 関する消散性妾有する。

証明 証明は定義 1を利用し解析することにより行なう。は じめに被制御量は,

$$
z=\left[\begin{array}{c}
\varepsilon_{1} \xi+\alpha \varepsilon_{1} J_{c}^{T}(q) e^{\hat{\theta}_{c}} \varphi(f) \\
\varepsilon_{2} \varphi(f)
\end{array}\right]
$$

であることに注意しておく. 不等式 (17) の解 $S$ として安 定性の証明で利用したリアプノフ関数 $V$ を利用する.この とき $k_{2}>0$ より関数 $V$ は正定関数である.式 (19)とり アプノフ関数の時間微分 (14) を不等式 (17) に代入すると,

$$
\begin{aligned}
& -k_{1}\|\xi\|^{2}-k_{2} \alpha\|\eta\|^{2}+\left[\begin{array}{ll}
-\xi^{T} & k_{2} \varphi^{T}(f) e^{-\hat{\theta}_{c}}
\end{array}\right] r \\
& \leq \frac{1}{2} \gamma^{2}\|r\|^{2}-\frac{\varepsilon_{1}^{2}}{2}\|\xi\|^{2}-\alpha \varepsilon_{1}^{2} \xi^{T} J_{c}^{T} e^{\hat{\theta}_{c}} \varphi(f) \\
& -\varphi^{T}(f)\left(\frac{\varepsilon_{2}^{2}}{2} I+\frac{\alpha^{2} \varepsilon_{1}^{2}}{2} e^{-\hat{\theta}_{c}} J_{c} J_{c}^{T} e^{\hat{\theta}_{c}}\right) \varphi(f)
\end{aligned}
$$

となる.この式を平方完成で変形することにより，

$$
\begin{aligned}
& -k_{1}\|\xi\|^{2}-k_{2} \alpha \varphi^{T}(f) e^{-\hat{\theta}_{c}} J_{c} J_{c}^{T} e^{\hat{\theta}_{c}} \varphi(f) \\
& +\frac{\varepsilon_{1}^{2}}{2}\|\xi\|^{2}+\alpha \varepsilon_{1}^{2} \xi^{T} J_{c}^{T} e^{\hat{\theta}_{c}} \varphi(f) \\
& +\varphi^{T}(f)\left(\frac{\varepsilon_{2}^{2}}{2} I+\frac{\alpha^{2} \varepsilon_{1}^{2}}{2} e^{-\hat{\theta}_{c}} J_{c} J_{c}^{T} e^{\hat{\theta}_{c}}\right) \varphi(f) \\
& \leq-\frac{1}{2 \gamma^{2}}\left[\begin{array}{ll}
-\xi^{T} & k_{2} \varphi^{T}(f) e^{-\hat{\theta}_{c}}
\end{array}\right]\left[\begin{array}{c}
-\xi \\
k_{2} e^{\hat{\theta}_{c}} \varphi(f)
\end{array}\right] \\
& +\frac{1}{2} \gamma^{2}\left\|r-\frac{1}{\gamma^{2}}\left[\begin{array}{c}
-\xi \\
k_{2} e^{\hat{\theta}_{c}} \varphi(f)
\end{array}\right]\right\|^{2} \ldots \ldots \cdots(20)
\end{aligned}
$$

式 (20) の右辺第 2 項以外は外生信号 $r$ 上は無関俰であ るので, $r=\frac{1}{\gamma^{2}}\left[\begin{array}{ll}-\xi^{T} & k_{2} \varphi^{T}(f) e^{-\hat{\theta}_{c}}\end{array}\right]^{T}$ としたときに 式 (20) が成立す机ば任意の $r \in L_{2} \cap L_{\infty}$ に対して不等式 (17) が成立することになる.よって，

$$
\begin{aligned}
& -k_{1}\|\xi\|^{2}-k_{2} \alpha \varphi^{T}(f) e^{-\hat{\theta}_{c}} J_{c} J_{c}^{T} e^{\hat{\theta}_{c}} \varphi(f) \\
& +\frac{\varepsilon_{1}^{2}}{2}\|\xi\|^{2}+\alpha \varepsilon_{1}^{2} \xi^{T} J_{c}^{T} e^{\hat{\theta}_{c}} \varphi(f) \\
& +\varphi^{T}(f)\left(\frac{\varepsilon_{2}^{2}}{2} I+\frac{\alpha^{2} \varepsilon_{1}^{2}}{2} e^{-\hat{\theta}_{c}} J_{c} J_{c}^{T} e^{\hat{\theta}_{c}}\right) \varphi(f) \\
& -\frac{1}{2 \gamma^{2}}\left[\begin{array}{ll}
-\xi^{T} & k_{2} \varphi^{T}(f) e^{-\hat{\theta}_{c}}
\end{array}\right]\left[\begin{array}{c}
-\xi \\
k_{2} e^{\dot{\theta}_{c}} \varphi(f)
\end{array}\right]
\end{aligned}
$$




$$
=-\left[\begin{array}{cc}
\xi^{T} & \varphi^{T}(f)
\end{array}\right] R\left[\begin{array}{c}
\xi \\
\varphi(f)
\end{array}\right] \leq 0 \cdots \cdots
$$

が成立するなら蛙不等式(17)の条件が成立する。

定理 2 の条件 $k_{2}>0, R>0$ は定理 1 の条件 $k_{1}>0$, $k_{2}>0, \alpha>0$ の十分条件となっている. よって定理 2 の条 件が満足されれば, 閏ループ系 (9)の安定性も保証される。

閉ループ (9)の外生信号 $r$ から被制御量 $z$ への $L_{2}$ ゲイ ンが $\gamma$ 以下となる判定基淮として $R$ の正定性を確認する 必要がある. しかし $R$ の正定性をを確認することは困難で ある. そこで制御性能を決定するパラメータ $\varepsilon_{1}, \varepsilon_{2}$ と $\gamma や$ 各今゙イン $k_{1}, k_{2}$ および $\alpha$ の満足する条件を遒出しておく. まず以下のような仮定を新たにおく。

【仮定 3] マニピェレータヤコビアン $J_{c}$ の最小特異值に は下極限值 $\beta>0$ 架存在する。つまり，

$$
\inf _{\mathrm{q} \in Q} \sigma_{\min }\left(J_{\mathrm{c}}\right)=\beta
$$

である.ここで $\sigma_{\text {min }}(\cdot)$ は行列の最小特異值とする.

仮定3が成立すればあきらかに仮定1は成立する．また仮定 3はマニピュレータの性能評価の指標の一つである可操作

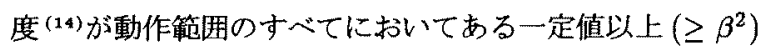
の値をとることを意味している.

この仮定のもとで $R$ が正定行列となる十分条件はつぎ のように与えられる.

〔系1〕制御目標を決定する $\varepsilon_{1}, \gamma$ は

$$
\beta>\frac{\varepsilon_{1}}{\gamma}
$$

を満足するようにあたえる.ここで，

$$
\begin{aligned}
& k_{1}>\frac{1}{2 \gamma^{2}}+\frac{\varepsilon_{1}^{2}}{2}+\frac{\varepsilon_{1}^{4}}{2 a} \ldots \ldots . \\
& \left(\frac{\beta^{2}}{4 b}-\frac{1}{2 \gamma^{2}}\right) k_{2}^{2}-\frac{\varepsilon_{2}^{2}}{2}>0 \ldots \ldots \\
& \alpha=\frac{k_{2}}{2 b} \ldots \ldots \ldots \ldots \ldots \ldots \ldots \ldots \ldots \\
& a:=\gamma^{2} \beta^{2}-\varepsilon_{1}^{2} \ldots \ldots \ldots \ldots \\
& b:=\frac{\varepsilon_{1}^{2}}{2}+\frac{\varepsilon_{1}^{4}}{4\left(k_{1}-\frac{1}{2 \gamma^{2}}-\frac{\varepsilon_{1}^{2}}{2}\right)}
\end{aligned}
$$

を満足するように $k_{1}$ と $k_{2}, \alpha$ をあたえることで行列 $R$ は正定行列となる。

証明 付録参照.

〔注意 4〕 系 1 より行列 $R$ の正定性は $k_{1}, k_{2}$ を十分大き く選ぶ，つまりハイゲインフィードバックにより達成で きることがわかる。ここで系 1 の条件は保守的な十分条 件となっていることに注意してもらいたい，つまり系 1 を満足しないダインの組でも行列 $R$ が正定となる場合
が存在する. しかし系 1 の条件は制御ゲインを決定する ためのひとつの指針となる. また次節で詳しく述べるが， 系1の条件を満足するように選んだ場合良好な追従特性 が実機において確認されている.

\section{5. 実 験 例}

本節では提案する制御則 (7) の有効性を示すために, 図 2 に示す実験装置により実験を行なった。

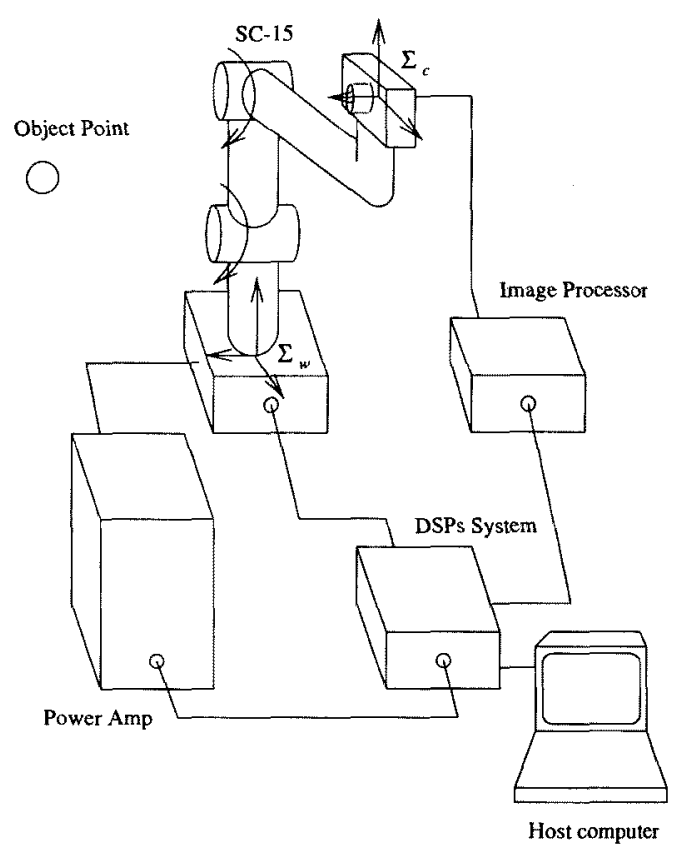

図 2 実験装置

Fig. 2. Experimental setup

〈5・1〉実験装貫の概要 Eye-in-hand システム: 本 システムでは産業用マニピュレータ (SC-15：(株) 不二越 製) を使用し，その手先効果器に CCD カメラ (CAM120 : (株) 応用計測研究所製)を取り付けて, eye-in-hand システ ムを構成した. カメラキャリブレーションを行なった結果 から焦点距離 $l$ とスケーリングファクタ $s$ の積 $s l$ は 2180 と同定できた. また使用した産業用マニピュレータは本来 6 軸であるが，その 2 番目と 3 番目の関節のみを駆動させ， 他の軸は物理的に拘束する。 つまり平面上を運動する 2 自 由度型平行リンク型マニピュレータとみなすことができる。

2 自由度平行リンク型マニピュレータダイナミクスはつ ぎのように与えられる。

$$
\begin{aligned}
& q=\left[\begin{array}{l}
q_{1} \\
q_{2}
\end{array}\right] \\
& M(q)=\left[\begin{array}{cc}
M_{11} & -M_{12} \cos \left(q_{2}-q_{1}\right) \\
-M_{12} \cos \left(q_{2}-q_{1}\right) & M_{22}
\end{array}\right]
\end{aligned}
$$




$$
\begin{aligned}
& C(q, \dot{q})=\left[\begin{array}{cc}
0 & \dot{q}_{2} M_{12} \sin \left(q_{2}-q_{1}\right) \\
\dot{q}_{1} M_{12} \sin \left(q_{1}-q_{2}\right) & 0
\end{array}\right] \\
& g(q)=\left[\begin{array}{l}
g_{11} \cos q_{1}+g_{12} \sin q_{1} \\
g_{21} \cos q_{2}+g_{22} \sin q_{2}
\end{array}\right] \\
& \text { ここで各パラメータは， } \\
& M_{11}=1.63 \times 10^{1} \quad\left[\mathrm{Nm}^{2}\right] \\
& M_{12}=-1.35 \times 10^{1} \quad\left[\mathrm{Nm}^{2}\right] \\
& M_{22}=1.20 \times 10^{1} \quad\left[\mathrm{Nm}^{2}\right] \\
& g_{11}=2.35 \times 10^{1} \quad[\mathrm{Nm}] \\
& g_{12}=-4.43 \times 10^{-1}[\mathrm{Nm}] \\
& g_{21}=-7.83 \quad[\mathrm{Nm}] \\
& g_{22}=-3.76 \quad[\mathrm{Nm}]
\end{aligned}
$$

である.なお㬰機においては摩摖力の影響が存在するが, 摩 擦力の定式化や同定は非常に困難である.そこで本稿では 外乱トルク $\omega$ として扱うこととし，陽に摩擦モデルを遒出 することは行なわないこととした。

またマニピュレータのフォワードキネマティクスとヤコ ビアンはそれぞれ

$$
\begin{aligned}
& c=\left[\begin{array}{l}
l_{1} \cos q_{1}-l_{2} \cos q_{2}+l_{3} \sin q_{2} \\
l_{1} \sin q_{1}-l_{2} \sin q_{2}-l_{3} \cos q_{2}
\end{array}\right] \\
& \theta_{c}=q_{2}-\pi \quad[\mathrm{rad}] \\
& J_{c}=\left[\begin{array}{cc}
-l_{1} \sin q_{1} & l_{2} \sin q_{2}+l_{3} \cos q_{2} \\
l_{1} \cos q_{1} & -l_{2} \cos q_{2}+l_{3} \sin q_{2}
\end{array}\right] \\
& J_{\theta_{c}}=\left[\begin{array}{ll}
0 & 1
\end{array}\right]
\end{aligned}
$$

である. そして各パラメータは,

$$
\begin{array}{ll}
l_{1}=6.00 \times 10^{-1} & {[\mathrm{~m}]} \\
l_{2}=3.98 \times 10^{-1} & {[\mathrm{~m}]} \\
l_{3}=7.50 \times 10^{-1} & {[\mathrm{~m}]}
\end{array}
$$

である. 厳密にいえば, マニピュレータのアクチュエータは すべて電動モータであるため，実際の入力としては適当な 電圧を入力することになる，その上，アクチュエータダイ ナミクスが存在するシステムとなる. 本実験装置ではモー 夕駆動装置 (AP 制御装置:(株) 不二越製)においてアクチュ エータダイナミクスを適切に補償するサーボループが組ま れており，それぞれの関節に指令トルクを直接入力するこ とが可能となっている.

画像処理装甾とティジタル制御装置：提案した制御則を実装 するために, 高速な画像処理装置 (Quick-Mag:(株) 忘用計 測研究所製) とDSP によるディジタル制御装置 (DSPCIT:dSPACE 社製) を利用した。画像処理装置は 120 $\mathrm{Hz}(8.3 \mathrm{~ms})$ のサンプリング周波数により対象の点像の 重心位置を計算する. ディジタル制御装置は, 9 つの DSP
(TMS320C40:TI 社製) と, 12 bit の分解能を有する D/A コンバータ, 24 bit のインクリメンタルエンコーダボード を有している. その制御則の計算周期は $1 \mathrm{~ms}$ である.

制御則 (7) の実装のためには, 関節速度 $\dot{q}$ 之特徵点の画 像面上の速度 $\dot{f}$ を計算する必要がある. 今回の実験では関 節角度 $q$ と特徽点の像 $f$ がそれぞれ $1 \mathrm{~ms}$ と $8.3 \mathrm{~ms}$ と十 分速い周期で得ることが可能であるため，その羑分による 近似值を利用することにした。

なおホストコンピュータ (IBM-PC 互換機:Gateway 2000 社製)に抽てすべての制御プログラムは $\mathrm{C}$ 言語により記述 される. そしてディジタル制御装置へダウンロードされる.

〈5・2〉実験用パラメータの設定 まず仮定 1 および 仮定 3 が満足されるように $q$ の動作範囲 $Q$ を,

$$
\begin{aligned}
& 1.57[\mathrm{rad}] \leq q_{1} \leq 2.22[\mathrm{rad}] \\
& 3.00[\mathrm{rad}] \leq q_{2} \leq 3.55[\mathrm{rad}]
\end{aligned}
$$

とする. この範用内ではヤコビアン $J_{c}$ のランクはすべて 2 となる. また $J_{c}$ の最小特異値の下限値は $\beta=9.30 \times 10^{-1}$ となる. 被制御量の重み係数は $\varepsilon_{1}=1.0 \times 10^{-1}, \varepsilon_{2}=$ $1.0 \times 10^{-3}$ とし, $L_{2}$ ゲインの上限值は $\gamma=2.0$ と定めた.

各ゲインは系 1 の条件をもとに表 1 のように 2 租決定 した. なお式 (24)(25)における不等号による自由度は，予 備実験により試行錯誤的に調整した．また飽和を決定する パラメータ入は実験装置の発生させられるトルクの限界値 を考虑して 2.0 とした，

表 1 制御則のダイン

Table 1. The controller gains

\begin{tabular}{|l|r|r|}
\hline 記号 & ダイン A & グイン \\
\hline$k_{1}$ & $1.50 \times 10^{2}$ & $1.50 \times 10^{2}$ \\
\hline$k_{2}$ & $2.00 \times 10^{-3}$ & $8.00 \times 10^{-4}$ \\
\hline$\alpha$ & $1.00 \times 10^{-2}$ & $4.00 \times 10^{-3}$ \\
\hline
\end{tabular}

ここでダイン A のパラメータは采 1 の条件を満足してい る. しかしゲイン B のパラメータでは式 (25) の条件を満 足しない，そして，定理 2 の行列 $R$ の正定性の条件も満足 しない組であるため, システムの $L_{2}$ グインが $\gamma=2.0$ 以 下となることが保証されていない場合の例である。

〈5.3〉 実験結果 䧽測する対象点の初期位置は $p(0)=$ $\left[\begin{array}{ll}0.79 & 1.09\end{array}\right]^{T}[\mathrm{~m}], z_{p}=z=1.86[\mathrm{~m}]$ である. そして $p=\left[\begin{array}{lll}0.37 & 1.30\end{array}\right]^{T}[\mathrm{~m}]$ の位置一 7 秒間で等速直線運動で 移動させる. 移動後 2 秒停止して, 再び初期位置へ 7 秒で 戻る動作を行なわせた。

カメラの初期位置は $c(0)=\left[\begin{array}{ll}0.79 & 1.09\end{array}\right]^{T}[\mathrm{~m}], \theta_{c}(0)=$ $0.00[\mathrm{rad}]$ であり, 対象点の像と関節速度の初期值は $f(0)=$ $\left[\begin{array}{ll}0 & 0\end{array}\right]^{T}[$ pixels $], \dot{q}(0)=\left[\begin{array}{lll}0.00 & 0.00\end{array}\right]^{T}[\mathrm{rad} / \mathrm{s}]$ とした.

図 3-5に実駼結果を示す。図3に坟対象点の画像面上の 位置の時間変化を示す，実線がグイン A の場合，破線がグ イン B の場合であり，上が $X_{i}$ 方向の位置を，下が $Y_{i}$ 方向 の位置を示している.また図 4 と 5には関節速度の時間変化 
を示す，図 4にはゲインA の場合, 図 5にはグインBの場 合が示されており，上が $\dot{q}_{1}$ を，下が $\dot{q}_{2}$ を示している.

対象が静止している 20 秒後以降の応答を図 3-5でみると ゲイン A および B の場合のどちらも画像面上の位置 $f$ と 関節速度 $\dot{q}$ す心てては 0 収束していることがかかる.つま り外生信号が存在しない場合の提案した制御則の安定性が 実機においても確認された。

対象点が移動する場合, 図 3 の画像面上の位置の時閒変化 がゲイン A の場合と B の場合で大きく異なっている. ゲ イン A の場合, つまり $L_{2}$ グインによる制御性能の指標を 満足している場合の方がより 0 一収束していることがわか る.つまり， $L_{2}$ ゲインによる外生信号のロバスト性を指標 として制御則を設計する妥当性が示されている。
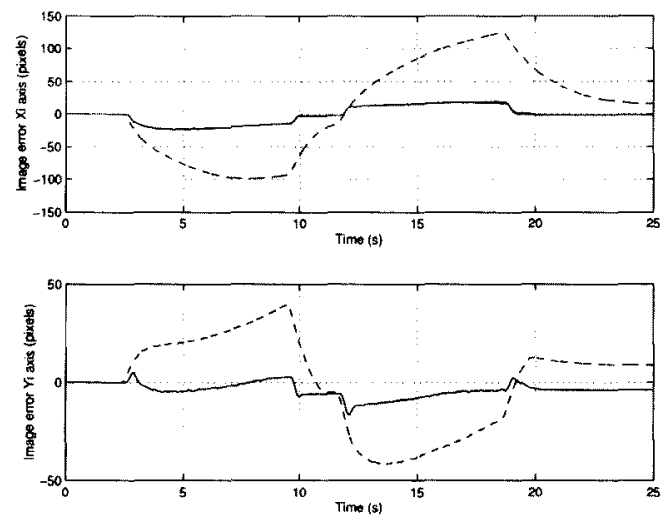

図 3 実験結果 (対象点の画像面上の位置 $f$ )

Fig.3. Experimental results (Image position $f$ )
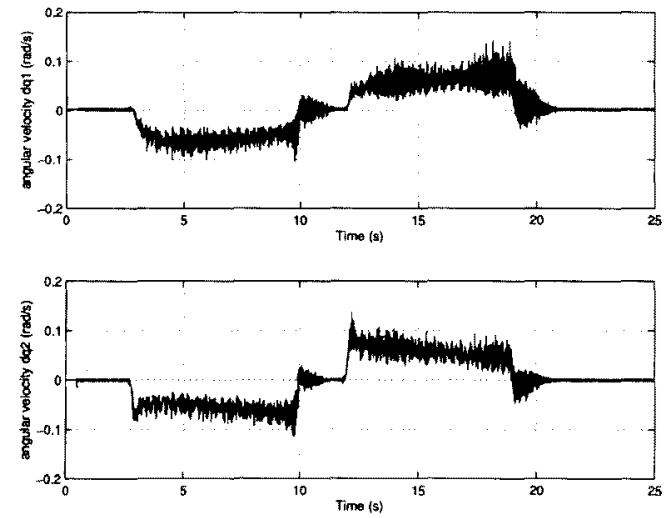

図 4 害験結果 (関節速度:ゲインAの場合)

Fig.4. Experimental results (Velocity : gain A)

\section{6.おわりに}

本稿では eye-in-hand 構造の視覚サーボシステムに対し て，マニピュレータのダイナミクスを考㢝し，提案する制御
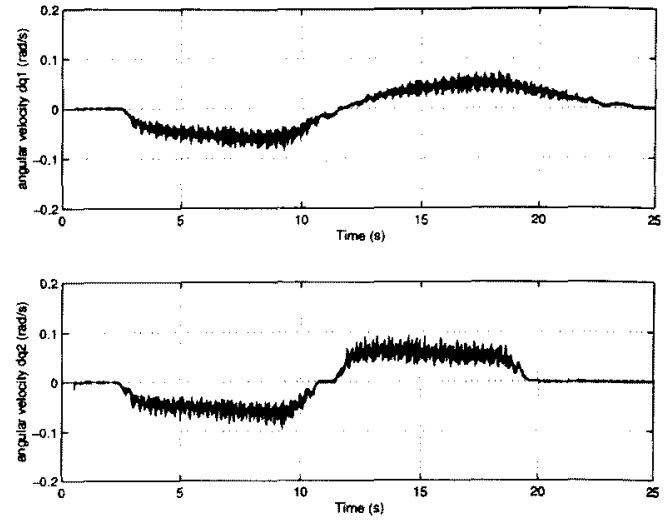

図 5 実験結果 (関節速度 : ゲインB の場合)

Fig. 5. Experimental results (Velocity : gain B)

則の安定性の解析と制御性能の評価を行なった. マニピュ レータダイナミクスを Euler-Lagrange システムとみなし て,そのシステムのもつ固有の性質を利用して安定性の解 析を行なった。

そして対象の運動とマニピュレータダイナミクスに加わ るトルク外乱を外生信号とすることを提案した. そして外 生信号に対するロバスト性を $L_{2}$ グインを利用して評価す ることで制御性能の解析も同時に行なった，それにより，系 の安定性を保証する制御則のゲインを調整することで制御 性能を満たすことができることが分かった. そして制御則 のゲインのとるべき条件を明示した.

また最後に実機により評価実験を行なうことで, 提案し た制御則の有效性と制御性能解析の妥当性を示した.

(平成 9 年 7 月 22 日受付, 同 9 年 10 月 22 日再受付)

\section{文献}

(1) R. Murray, Z. Li and S. S. Sastry, A Mathematical Introduction to Robotic Manipulation, CRC Press, 1994.

(2) S. Arimoto, Control Theory of Non-Linear Mechanical Systems, A Passivity-Based and Circuit-Theoretic Approach, Oxford Univ. Press, 1996.

(3) J. M.A. Scherpen and R. Ortega, "On Nonlinear Control of Euler-Lagrange Systems: Disturbance Attenuation Properties," System \& Control Letters, Vol. 30, pp. 49-56, 1997.

(4) S. Hutchinson, G. D. Hager and P. I. Corke, "A Tutorial on Visual Servo Control," IEEE Trans. Robotics and Automation, Vol. 12, No. 5, pp. 651-670, 1996.

(5) P. I. Corke and M. C. Good, "Dynamic Effects in Visus Closed-Loop Systems," IEEE Trans. Robotics and Automation, Vol. 12, No. 5, pp. 671-683, 1996.

(6) B. J. Nelson, N. P. Papanikolopoulos and P. K. Khosla, "Robotic Visual Servoing and Robotic Assembly Tasks," $I E E E$ Robotics and Automation Magazine, pp. 23-31, June 1896.

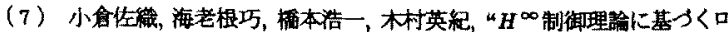
ボットの視覚フィードバック制御,”計测自野制御学会詥文集, Vol. 30, No. 12 , pp. 1505-1611, 1994.

（8）㰌本浩一，木村英䄫，“ビシュアルサーボイングー非線形オノザーパ アプローチ-,"日本ロボット学会誌, vol. 13, no. 7, pp. 986-893, 1095.

(9) A. Maruyama and M. Fujita, "Robust Visual Servo for Pla- 
nar Manipulators with Image Feature Parameter Potential," Proc. of the 2nd ASCC, Seoul, Korea, Vol. 3, pp. 331-334, 1997.

(10) A. Maruyama and M. Fujita, "Robust Visual Servo Control of Planar Manipulators with the Eye-in-Hand Configuration," Proc. of 36th IEEE CDC, San Diego, CA, pp. 2551-2552, 1997.

(11) R. Kelly, "Robust Asymptotically Stable Visual Servoing of Planar Robots," IEEE Trans. Robotics and Automation, Vol. 12, No. 5, pp. 759-766, 1996.

(12) R. Kelly, R. Carelli, O. Nasisi, B. Kuchen and F. Reyes, "A Stable Visual Servo Controller for Camera-in-Hand Robotic Systems," Proc. of ICAR, Monterey, CA, 1997.

(13) A. van der Schaft, $L_{2}-$ Gain and Passivity Techniques in Nonlinear Control, Lecture Notes in Control and Information Sciences, 218, Springer-Verlag, 1996.

（14）吉川恒夫, “ロボット制御基磷論,”コロナ社, 1 b88.

（15）児玉慎三，須田伸英，“システム制御のためのマトリクス理論,”計 测自動制御学会, 1992 .

\section{付 録}

\section{1. 補題 1 の証明}

$\left[\dot{q}^{T} f^{T}\right]^{T}=0$ ならぼ, $\left[\xi^{T} \eta^{T}\right]^{T}=0$ はあきらかである. $\left[\xi^{T} \eta^{T}\right]^{T}=0$ より $\dot{q}$ は 0 となる. また $J_{\mathrm{c}}$ が行フルラン クより $\eta=0$ ならば $\varphi(f)=0$ である. ここで性質 3 より $f=0$ となる.

\section{2. 性質 4, 5 の証明}

まず $y(x):=\|x\|$ と定義すると式 (11) は

$$
U(y(x))=\frac{1}{\lambda}\left(y-\frac{1}{\lambda} \log (1+\lambda y)\right)
$$

であり $y$ のとる範用は $[0, \infty)$ である. これを $y$ に関して 微分すると

$$
\frac{\partial U}{\partial y}=\frac{y}{1+\lambda y}
$$

であるので, $y \geq 0$ ではあきらかに $\frac{\partial U}{\partial y} \geq 0$ となり, 等号が 成立するのは $y=0$ のみである. つまり $y=0$ のとき最小 值 $U(0)=0$ をとる. つまり性質 4 が成立する.

つぎに $y=\|x\|$ の $x$ に関するヤコビアンを計算すると，

$$
\frac{\partial y}{\partial x}=\frac{x^{T}}{y}
$$

となる.よって

$$
\frac{\partial U}{\partial x}=\frac{\partial U}{\partial y} \frac{\partial y}{\partial x}=\frac{y}{1+\lambda y} \frac{x^{T}}{y}
$$

である.つまり性質 5 が成立する.

\section{3. 系 1 の証明}

行列 $R$ が正定行列となる必要十分条件は，

$$
\begin{aligned}
R_{11} & >0 \\
R_{22}-R_{12}^{T} R_{11}^{-1} R_{12} & >0
\end{aligned}
$$

で与えられる(15)

$$
k_{1}-\frac{1}{2 \gamma^{2}}-\frac{\varepsilon_{1}^{2}}{2}=r_{11}>0
$$

電学論C, 118 巻 3 号, 平成 10 年
を満足するように $k_{1}$ を定めるならば $R_{11}=r_{11} I>0$ が 成立する.つぎに (付 6) より，

$$
\begin{aligned}
R_{22} & -R_{12}^{T} R_{11}^{-1} R_{12} \\
= & -e^{-\hat{\theta}_{c}} J_{c} J_{c}^{T} e^{\hat{\theta}_{c}}\left(\left(\frac{\varepsilon_{1}^{2}}{2}+\frac{\varepsilon_{1}^{4}}{4 r_{11}}\right) \alpha^{2}-k_{2} \alpha\right) \\
& -\left(\frac{k_{2}^{2}}{2 \gamma^{2}}+\frac{\varepsilon_{2}^{2}}{2}\right) I \\
= & -e^{-\hat{\theta}_{c}} J_{c} J_{c}^{T} e^{\hat{\theta}_{c}} b\left(\alpha-\frac{k_{2}}{2 b}\right)^{2} \\
& +\frac{k_{2}^{2}}{4 b} e^{-\hat{\theta}_{c}} J_{c} J_{c}^{T} e^{\hat{\theta}_{c}}-\frac{k_{2}^{2}}{2 \gamma^{2}} I-\frac{\varepsilon_{2}^{2}}{2} I
\end{aligned}
$$

$\alpha=\frac{k_{2}}{2 b}$ と選ぶことで

$$
\begin{aligned}
& R_{22}-R_{12}^{T} R_{11}^{-1} R_{12} \\
& =\frac{k_{2}^{2}}{4 b} e^{-\hat{\theta}_{c}} J_{c} J_{c}^{T} e^{\hat{\theta}_{c}}-\frac{k_{2}^{2}}{2 \gamma^{2}} I-\frac{\varepsilon_{2}^{2}}{2} I
\end{aligned}
$$

となる.ここで仮定 3 を利用すると

$$
\begin{aligned}
& R_{22}-R_{12}^{T} R_{11}^{-1} R_{12} \\
& \geq\left(\left(\frac{\beta^{2}}{4 b}-\frac{1}{2 \gamma^{2}}\right) k_{2}^{2}-\frac{\varepsilon_{2}^{2}}{2}\right) I
\end{aligned}
$$

をえる. 式(付 7) が正定となる条件は，

$$
\begin{array}{r}
\frac{\beta^{2}}{4 b}-\frac{1}{2 \gamma^{2}}>0 \\
\left(\frac{\beta^{2}}{4 b}-\frac{1}{2 \gamma^{2}}\right) k_{2}^{2}-\frac{\varepsilon_{2}^{2}}{2}>0
\end{array}
$$

である.つまり(付 8)，(付 9) をそれぞれ満足するように， $k_{1} ， k_{2}$ を与えれば行列 $R$ は正定行列となる.
丸山

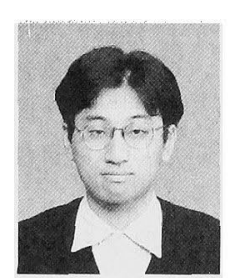

1969 年生. 1992 年 3 月 金沢大学工学部電気情報 工学科卒業. 1994 年 北陸先端科学技術大学院大 学情報科学研究科, 博士前期課程修了. 同年 (株) 不二越入社. 1996 年北陸先端科学技術大学院大 学情報科学研究科, 博士後期課程在籍. 視覚サ一 ボに関する研究に従事. 計測自動制御学会, 日本 ロボット学会の会員.

藤 田 政 之（正員）電学論 Vol. 118-C, No. 2 参照. 